간동맥주입 화학요법과 체외 방사선 치료의 병행요법으로 치료한 국소 진행성 간세포암종 1 예

양태영 · 신석표 · 이주호 · 이윤빈 · 박하나 · 황성규 · 임규성

차의과학대학교 분당차병원 소화기내과

\title{
A Case of Concurrent Chemoradiation Therapy for Locally Advanced Hepatocellular Carcinoma with Portal Vein Thrombosis
}

\author{
Tae Young Yang, Suk Pyo Shin, Joo Ho Lee, Yun Bin Lee, Hana Park, Seong Gyu Hwang, Kyu Sung Rim \\ Division of Gastroenterology, Department of Internal Medicine, CHA Bundang Medical Center, CHA University School of Medicine, \\ Seongnam, Korea
}

Received Mar. 4, 2015

Revised Mar. 20, 2015

Accepted Mar. 23, 2015
Patients with advanced hepatocellular carcinoma (HCC) with portal vein thrombosis (PVT) have an extremely poor prognosis. Although the Barcelona Clinic Liver Cancer guideline recommends sorafenib in advanced HCC with PVT, which has provided survival benefits of 2 or 3 months compared to the placebo group, many liver cancer centers in Asia still select multimodality approaches including transarterial chemoembolization, radiofrequency ablation, radiation therapy (RT) as well as systemic/intra-arterial chemotherapy. Recently advanced RT technologies have shown potential to improve survival without severe radiationrelated toxicity. For locally advanced HCC patients with PVT, concurrent chemoradiotherapy (CCRT) has been applied as a loco-regional treatment and provides potential cures. We herein report our recent experience of a patient accompanying large HCC with PVT who successfully undergone CCRT followed by hepatic arterial infusion chemotherapy. (Journal of Liver Cancer 2015;15:52-56)

Keywords: Hepatocellular carcinoma; Concurrent chemoradiotherapy
서 론

간세포암종은 진단 당시에 간절제술 또는 간이식 등의 근치적 제거술이 불가능한 진행된 병변을 보이는 경우가 전체 간세포암종 중의 $70-90 \%$ 정도를 차지한다. ${ }^{1}$ 이러한 경우에 고주파 열치료술과 같은 국소 치료술 및 경동맥 화 학색전술(transarterial chemoembolization, TACE), 체외방

\section{Corresponding author: Joo Ho Lee}

Department of Internal Medicine, CHA Bundang Medical Center, CHA University School of Medicine, 59 Yatap-ro, Bundang-gu, Seongnam 463-712, Korea

Tel. +82-31-780-5212, Fax. +82-31-780-5219

E-mail; piolee2000@naver.com
사선 치료(radiation therapy, RT) 등의 비수술적 치료 방법 들이 시도되고 있다. ${ }^{2}$ 간세포암에 대한 방사선 치료는 주로 간기능이 Child-Pugh 등급 A 또는 상위 B인 경우 시행되고 있으며 $40-90 \%$ 의 반응률과 $10-25$ 개월의 중앙생존 기간을 보고하고 있다. ${ }^{3}$ 방사선 치료는 간문맥 종양혈전증(portalvein tumor thrombosis, PVTT) 유무에 제한을 받지 않고 안전하게 시행할 수 있는 장점이 있어, 2014년 대한간암학 회의 간세포암종 진료 가이드라인에서는 종양혈전증을 동 반한 국소 진행성 간세포암종에서 간기능이 보존되고 전 산화 방사선 치료 계획 시 $30 \mathrm{~Gy}$ 이상을 조사 받는 간부피 가 전체 간부피의 $60 \%$ 이하인 경우 체외 방사선 치료를 시 행할 수 있다고 권고하고 있다. ${ }^{4}$ 국소 진행된 간세포암종에 서 간동맥주입 화학요법과 체외 방사선 치료의 병행치료 
(concurrent chemoradiotherapy, CCRT)는 $24.1 \%$ 의 3 년 생 존율 및 13.1 개월의 중앙생존 기간을 보고하였다. ${ }^{5}$ 또한 최 근에는 이러한 CCRT를 통해 국소 진행성 간세포암을 이른 바 “downstaging” 후 수술을 시행함으로써 무병생존율의 향상을 보여주었다. ${ }^{6}$ 이에 본 저자들은 PVTT를 동반한 국 소 진행성 간세포암 환자에서 CCRT 시행 후 PVTT와 원발 종양은 호전되었으나, 새로운 간내 전이(liver to liver metastasis)를 보인 증례를 경험하였기에 이를 보고하는 바 이다.

\section{증 례}

\section{1. 임상소견}

고혈압 병력이 있는 59세 남자 환자가 과거 만성 B형 간 염 보유자로 진단 받았으나 주기적인 검사는 하지 않고 지 내다가 내원 1 개월 전부터 우측 상복부 통증이 지속되어 외 래로 내원하였다. 아버지가 후두암, 어머니가 간암으로 사 망한 가족력이 있었다. 음주력은 주 3-4회, 매회 소주 1-2 병, 30 년간 있었으며 40 갑년의 흡연력이 있었다. 문진소견 에서 경미한 복부 불편감이 있었다. 이학적 검사에서 공막 의 황달소견은 없었으며, 복부는 편평하고 부드러웠다. 우 상복부의 경미한 압통을 호소하였으나 반발통은 없었으 며, 간이나 비장은 촉지되지 않았다. 내원 당시 시행한 일반 혈액검사상 백혈구 $11,800 / \mathrm{uL}$, 혈색소 $16.0 \mathrm{~g} / \mathrm{dL}$, 혈소판
$214.000 / \mathrm{uL}$ 였다. 일반화학검사에서는 총 단백 $7.9 \mathrm{~g} / \mathrm{dL}$, 알 부민 $4.7 \mathrm{~g} / \mathrm{dL}$, aspartate aminotransferase (AST)/ alanine aminotransferase (ALT) 165/275 IU/L, total bilirubin 1.92 $\mathrm{mg} / \mathrm{dL}$, alkaline phosphate $709 \mathrm{IU} / \mathrm{L}$, gamma-glutamyl transpeptidase $378 \mathrm{IU} / \mathrm{L}$ 였다. 혈액응고검사상 PT 108\%였으며, 종양 표지자검사상 알파태아단백(alpha-fetoprotein, AFP) $5.7 \mathrm{ng} / \mathrm{mL}$, protein induced by vitamin $\mathrm{K}$ absence or antagonist-II (PIVKA-II) 3,065 mAU/mL였고, 바이러스간염 표지 자 검사상 $\mathrm{HBsAg}(+), \mathrm{HBeAg}(-)$, anti-HBe (+), HBV DNA titer 2,712 IU/mL, anti-hepatitis C virus antibody (-)였다. 만 성 B형 간염에 대한 치료로 tenofovir 투여를 시작하였다.

\section{2. 영상소견}

복부 전산화 단층촬영에서 간우엽에 $10 \mathrm{~cm}$ 이상의 경계 가 명료한 종괴가 관찰되었으며 동맥기에 조영 증강 및 문 맥기에 조기배출을 보여 간세포암종에 합당한 소견을 보 였다. 우측 간문맥으로의 침윤소견이 있었으며 주간문맥 에 종양 혈전 침범소견이 있었다(Fig. 1). 간경화가 진행된 소견이었으며 위내시경에서는 식도정맥류가 관찰되었다. 양전자방출 단층촬영에서는 동일한 부위의 간우엽에 신호 증강이 있었으며, 주간문맥과 우측 간문맥에 신호증강이 있어 종양의 우측 간문맥 침윤 및 간문맥의 PVTT 소견을 보였다.
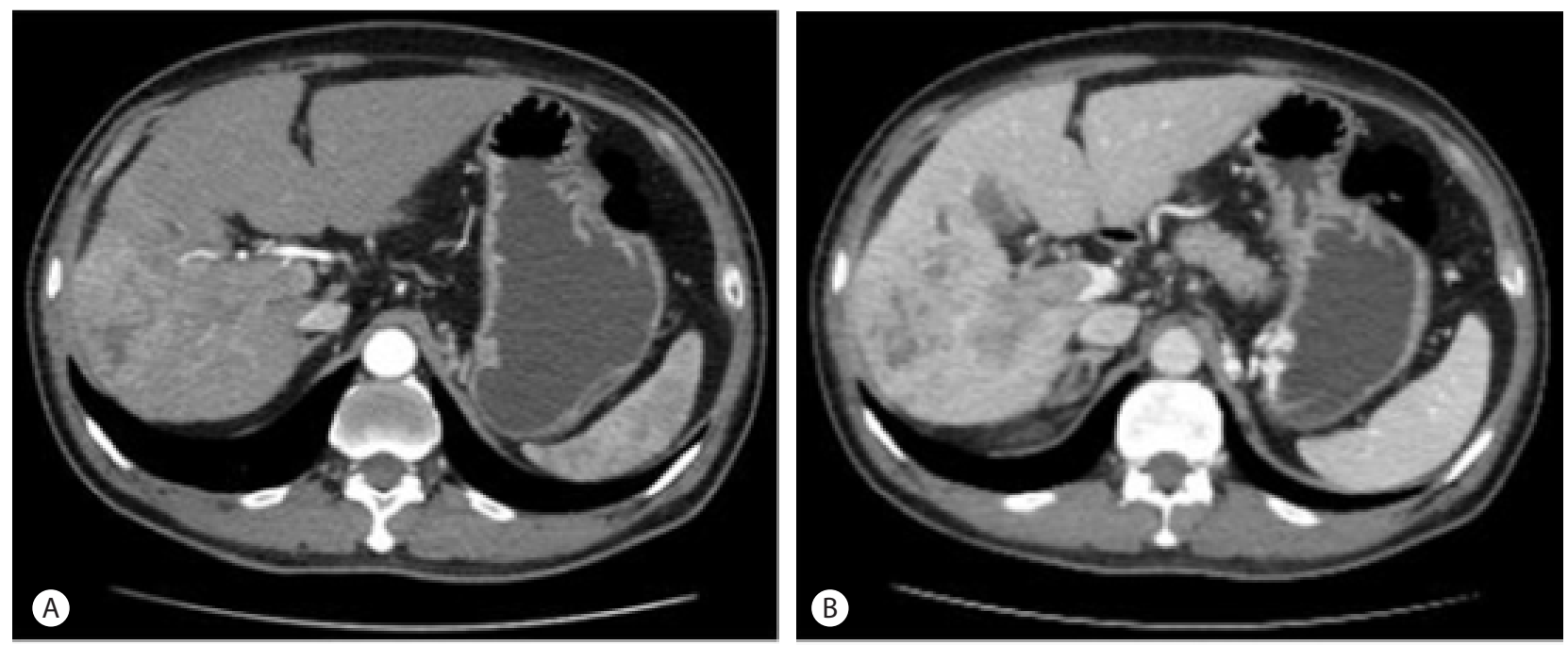

Figure 1. Infiltrative HCCs in right lobe of liver with arterial enhancement (A) and delayed wash-out of contrast (B) accompanying malignant portal vein tumor thrombosis in right portal vein. HCC, hepatocellular carcinoma. 


\section{3. 진단 및 치료경과}

상승된 종양표지자와 영상소견에 의해 만성 B형 간염에 따른 간경변, Chil-Phugh A 등급, 간세포암(modified Union Internationale Contre le Cancer [UICC] stage IV A)으로 진 단하였다. 간동맥주입 화학요법 및 방사선동시치료법(간 동맥내 5-fluorouracil (5-FU) 주입은 RT 시작 5일간 및 종 료 전 5일간 시행+총 $3,000 \mathrm{cGy}$ [ $100 \mathrm{cGy} \times 30$ 회])을 ${ }^{5}$ 시작하 였으며 추적 관찰한 복부 전산화 단층촬영에서 간우엽에 원발 종양은 크기가 줄어들었으며 간문맥 종양 침윤 및 PVTT도 호전된 소견을 보였다(Fig. 2). 동시에 간좌엽에 새 로이 미세한 조영 증가가 의심되는 소견이 함께 보였다
(Fig. 3). 부분 반응 평가하에 추가적인 간동맥 내 항암제 주 입요법(hepatic arterial infusion chemotherapy, HAIC)을 3 차에 걸쳐 5-FU/cisplatin (CDDP)으로 진행하였다. 3번째 $\mathrm{HAIC}$ 를 위해 입원하여 진행한 간동맥 조영술상 간동맥 박 리 소견을 보여 풍선확장술을 시행하였으며 더 이상의 동 맥박리 소견은 없어 경과관찰하기로 하였다. 2 개월 뒤 추적 한 복부 전산화 단층촬영에서 간경변의 진행에 의한 복수 증가와 간좌엽으로의 다발성 전이 $(<2 \mathrm{~cm})$ 가 있었으나(Fig. 4), 간우엽의 원발종괴는 더 이상 진행되지 않았고 간문맥 의 침윤 및 PVTT의 호전은 유지되었다(Fig. 5). 복수에 대 한 이뇨제 투여 등 지지적 치료 후 향후 간기능 호전 시 $\mathrm{TACE}$ 또는 추가적인 HAIC 계획 중이다.
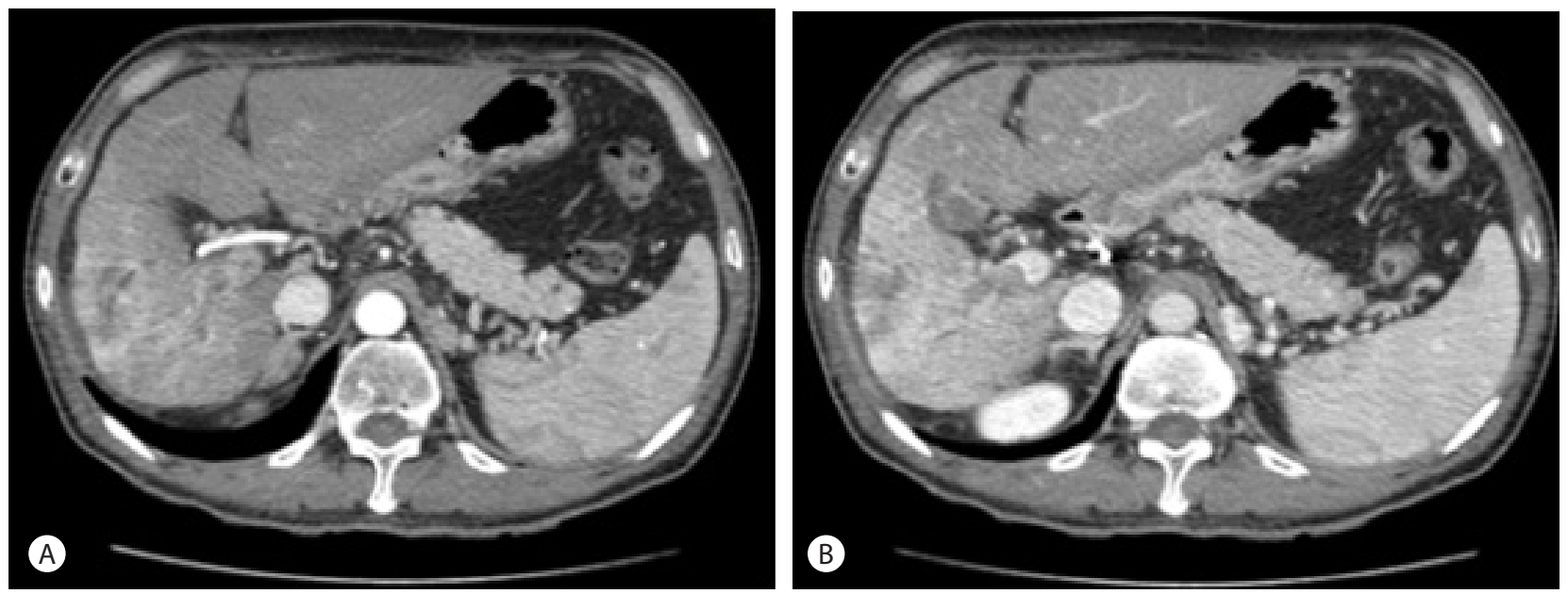

Figure 2. Compared to the previous CT scan, mild regression of infiltrative HCCs in the right lobe of liver (A) with malignant thrombi in right portal vein (B). CT, computed tomography; HCC, hepatocellular carcinoma.
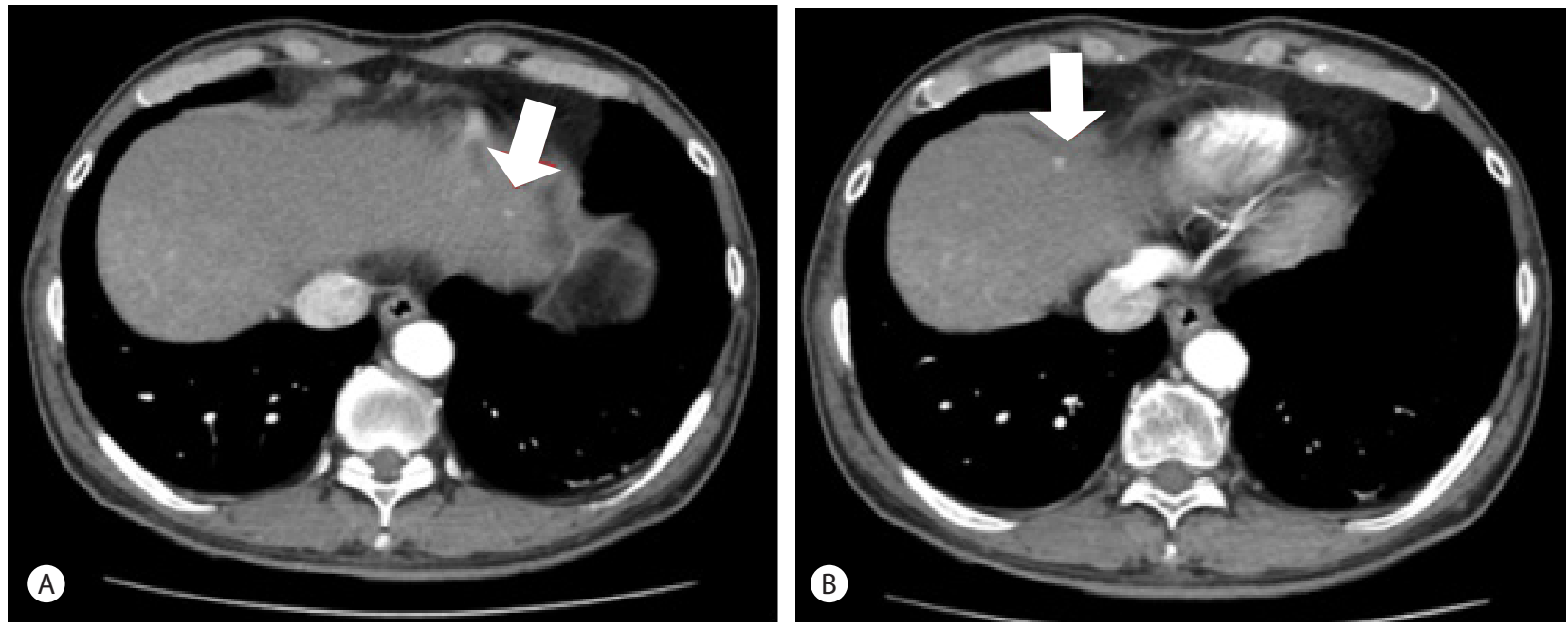

Figure 3. Multiple small to tiny arterial enhancing lesions (without subsequent washout) at segment II (A) and at segment IV (B) on the left lobe of liver, indicated by arrows. 


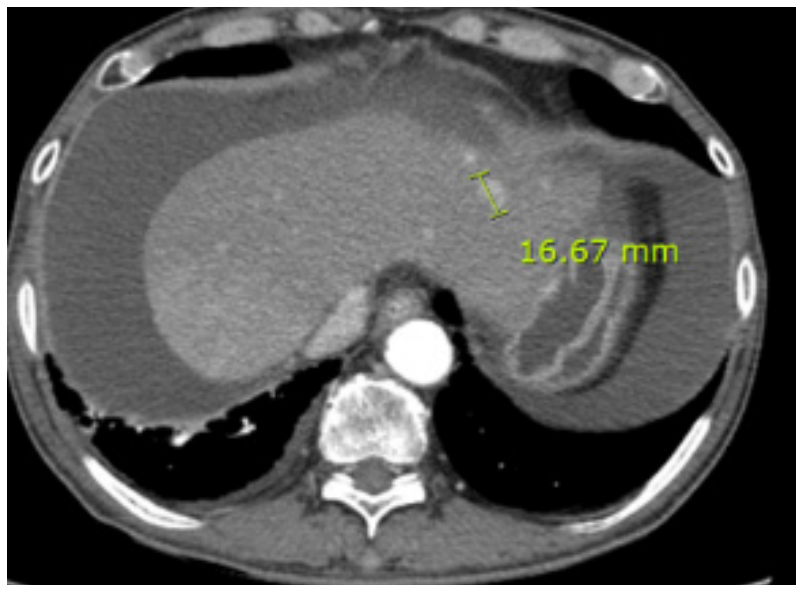

Figure 4. Mild progression of liver to liver metastatic lesions in the left lobe of liver and increased ascites.

\section{고 찰}

간세포암종으로 진단 받은 환자들은 첫 진단 시 간이식 이나 수술 같은 근치적 절제술을 할 수 없는 경우가 대부분 이다. ${ }^{2}$ 소라페닙이 진행된 간암 환자에서 약 3 개월 정도의 생존기간의 유의한 증가가 보고되었으나, ${ }^{7}$ Child-Pugh 등 급 $\mathrm{A}$ 의 간기능을 가진 환자와 Barcelona Clinic Liver Cancer 병기 C인 환자들을 주 대상으로 해서 많은 환자에게 적용 하기가 힘들며 생존기간의 증가도 3 개월이 채 되지 않아 많 은 환자들과 의사들을 만족시키기 힘들다. 가격 또한 저렴 한 편이 아니다.

하지만 진행된 간암에서 항암화학요법이 소라페닙에 비 해 생존기간에 미치는 효과가 열등하지 않다는 연구도 있 으며, ${ }^{8}$ 대한간암연구회와 국립암센터가 만든 간세포암종 진료 가이드라인에 따르면 간기능이 Child-Pugh 등급 A 또 는 상위 B 등급이면서 종양이 전체 간부피의 $2 / 3$ 이하인 경 우 RT를 시행할 수 있다고 했고 또한 PVTT를 동반한 간세 포암종에 방사선 치료를 시행할 수 있다고 하였다. ${ }^{4}$ CCRT 가 생존기간의 증가와 종양 반응에 효과가 있다는 연구도 있다. ${ }^{9}$

본 증례에서는 PVTT를 동반한 국소적으로 진행된 Child-Pugh 등급 A 간암에서 CCRT를 시행하였고 이후 시 행한 복부 computed tomography $(\mathrm{CT})$ 에서 표적 병변의 불 변 소견을 관찰할 수 있었지만 표적부위가 아닌 곳에서 새 로운 병변이 발생하였다. 수차례의 HAIC를 시행하며 현재 까지 진단 후 12 개월 넘게 생존하고 있으나 간 기능이 저하

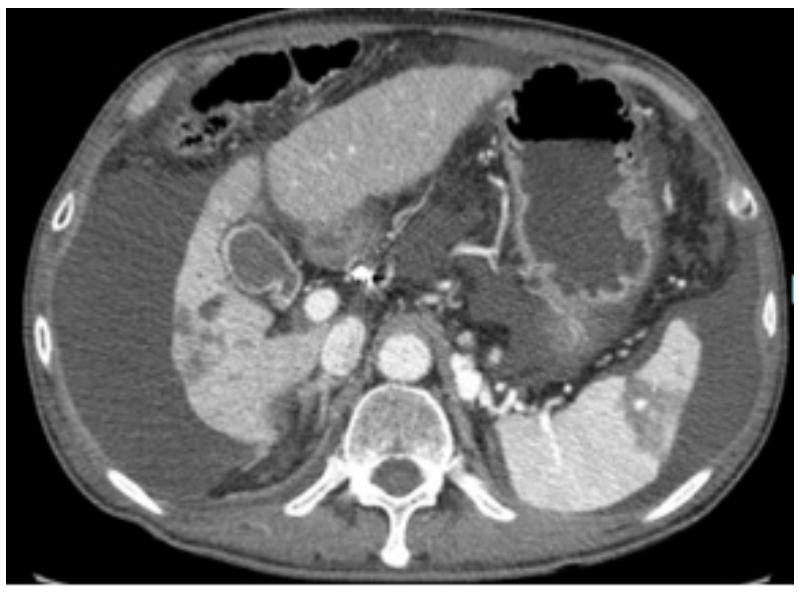

Figure 5. Compared to the previous CT scan, no change or slight regression of infiltrative HCCs in the right lobe of liver with malignant thrombi in right portal vein. CT, computed tomography; $\mathrm{HCC}$, hepatocellular carcinoma.

되었다.

최근 국소진행성 간세포암에서 동시 항암 화학방사선요 법과 경동맥 항암화학요법이 PVTT의 완전 관해(complete response, $\mathrm{CR}$ )와 부분 관해(partial response, PR)를 각각 $14 \%$ 와 $48 \%$ 이루었으며, 이때 PVTT의 완전 관해가 독립된 예후인자가 된다고 보고된 바 있다. ${ }^{10}{ }^{ㅂ ㅗ ㄴ ~ ㅈ ㅡ ㅇ ㄹ ㅖ ㅇ ㅔ ㅅ ㅓ ㄴ ㅡ ㄴ ~ ㄷ ㅗ ㅇ ㅅ ㅣ ~}$ 항암 화학방사선요법 후 PVTT가 부분 관해를 이루었고, $\mathrm{HAIC}$ 를 추가로 시행 후 추가적인 반응을 관찰하여 완전 관 해를 이루는지 여부를 확인해야 하겠다.

진행된 간세포암은 다발성으로 퍼지는 경향이 강하고 거 시적 혹은 미시적 혈관침입이 흔하게 보고된다. 이로 인해 진행된 간암에서 영상학적으로 감지할 수 없는 간 내 혹은 간 외 전이가 흔히 있으며 이런 전이성 병변은 방사선요법 으로는 효과적으로 치료할 수 없다. ${ }^{11}$ 이런 문제를 줄이기 위해 본 증례에서 동시 항암 화학방사선 요법(CCRT) 시행 이후 경동맥 항암화학요법(HAIC)을 수차례 시행하였으나 전이를 막지는 못하였다. 최근 간 내 전이를 동반한 간암에 서 TACE 후 CCRT와 HAIC가 효과를 봤다는 연구가 있어 고려할 수 있겠다. ${ }^{12}$ 본 증례에서 발생한 간기능의 저하는 항암화학요법 후 B형 간염의 활성화가 원인이 될 수 있으 나 본 증례에서는 tenofovir를 지속적으로 투여한 결과 간 염의 활성화는 없어 방사선으로 인한 간손상(radiation induced liver disease)으로 설명할 수 있겠다. 국소적으로 진 행된 간세포암에서 동시 항암 화학방사선 요법(CCRT)은 표적 병변의 치료에 비교적 효과적이고 생존기간의 증가 에 도움이 될 수 있으나, 간기능 저하 등의 부작용이 발생할 
수 있으므로 환자의 상태에 맞는 적절한 치료 계획을 세우

는 것이 중요하리라고 본다.

중심 단어: 간세포암; 방사선 치료

\section{Conflicts of Interest}

The authors have no conflicts to disclose.

\section{REFERENCES}

1. Shi XJ, Jin X, Wang MQ, Wei LX, Ye HY, Liang YR, et al. Effect of resection following downstaging of unresectable hepatocelluar carcinoma by transcatheter arterial chemoembolization. Chin Med J (Engl) 2012;125:197-202.

2. Bruix J, Sherman M; Practice Guidelines Committee. American Association for the Study of Liver Diseases. Management of hepatocellular carcinoma. Hepatology 2005;42:1208-1236.

3. Hawkins MA, Dawson LA. Radiation therapy for hepatocellular carcinoma: from palliation to cure. Cancer 2006;106:1653-1663.

4. Lee JM, Park JW, Choi BI. 2014 KLCSG-NCC Korea Practice Guidelines for the management of hepatocellular carcinoma: HCC diagnostic algorithm. Dig Dis 2014;32:764-777.

5. Han KH, Seong J, Kim JK, Ahn SH, Lee do Y, Chon CY. Pilot clinical trial of localized concurrent chemoradiation therapy for locally advanced hepatocellular carcinoma with portal vein thrombosis. Cancer 2008;113:995-1003.

6. Lee IJ, Kim JW, Han KH, Kim JK, Kim KS, Choi JS, et al. Concurrent chemoradiotherapy shows long-term survival after conversion from locally advanced to resectable hepatocellular carcinoma. Yonsei Med J 2014;55:1489-1497.

7. Llovet JM, Ricci S, Mazzaferro V, Hilgard P, Gane E, Blanc JF, et al. Sorafenib in advanced hepatocellular carcinoma. N Engl J Med 2008:359:378-390.

8. Lee S, Yoon SH, Park JY, Kim do Y, Ahn SH, Han KH, et al. Sorafenib versus cytotoxic chemotherapy for patients with advanced hepatocellular carcinoma: a retrospective, single-institution study. Invest New Drugs 2012;30:1150-1157.

9. Dawson LA, McGinn CJ, Normolle D, Ten Haken RK, Walker S, Ensminger $W$, et al. Escalated focal liver radiation and concurrent hepatic artery fluorodeoxyuridine for unresectable intrahepatic malignancies. J Clin Oncol 2000;18:2210-2218.

10. Choi Y, Kim JW, Cha H, Han KH, Seong J. Overall response of both intrahepatic tumor and portal vein tumor thrombosis is a good prognostic factor for hepatocellular carcinoma patients receiving concurrent chemoradiotherapy. J Radiat Res 2014;55:113-120.

11. Chung YL, Jian JJ, Cheng SH, Tsai SY, Chuang VP, Soong T, et al. Sublethal irradiation induces vascular endothelial growth factor and promotes growth of hepatoma cells: implications for radiotherapy of hepatocellular carcinoma. Clin Cancer Res 2006;12:27062715.

12. Park MS, Kim SU, Park JY, Kim do Y, Ahn SH, Han KH, et al. Combination treatment of localized concurrent chemoradiation therapy and transarterial chemoembolization in locally advanced hepatocellular carcinoma with intrahepatic metastasis. Cancer Chemother Pharmacol 2013;71:165-173. 